\title{
Influence of Stream Characteristics on Diversity and Distribution of Benthic Algae in Gongawwa Ela in Kottawa Rain forest, Galle, Sri Lanka
}

\author{
W.A.A.S. Chandrathilaka ${ }^{1}$, H.B. Asanthi ${ }^{1 *}$, T.G. Dayananda ${ }^{2}$, and R. G. Gunasekera ${ }^{2}$ \\ ${ }^{I}$ Department of Limnology and Water Technology, University of Ruhuna, Matara, Sri Lanka \\ ${ }^{2}$ Department of Botany, University of Ruhuna, Matara, Sri Lanka
}

\begin{abstract}
Influence of stream characteristics on diversity and distribution of benthic algae were studied at Gongawwa Ela during the period of September to November in 2016. Four sampling sites were selected and the distance between two sampling sites was $1.5 \mathrm{~km}$. Substrate types were categorized by sieve analysis and grain size distribution curves. Principle Component Analysis (PCA) was performed to identify the most important stream characteristics that could potentially influence on the growth of benthic algae. Physicochemical characteristics of water (nitrate, Total Dissolved Solids, temperature, $\mathrm{pH}$, and Dissolved Oxygen) and substrates ( $\mathrm{pH}$, phosphate and nitrate) showed significant temporal variations. Conductivity and water velocity levels of the substrate varied significantly among the sampling sites. Species richness of benthic algae (29 genera) showed significantly negative correlations with the level of phosphate content $(\mathrm{R} 2=-$ $0.9592, \mathrm{P}<0.05)$ and $\mathrm{pH}$ levels $(\mathrm{R} 2=-0.999, \mathrm{P}<0.05)$ of the substrate. Well graded substrate was observed only at the most downstream site (site 3) while other sites showed poorly graded substratum consisting over $90 \%$ of sand. The most abundant algal division was Bacillariophyta and the abundance of Flagilaria sp., Pinnularia sp., Stigeoclonium sp., and Pediastrum sp. showed significant temporal variation. Pinnularia sp., Synedra sp., Anabaena sp. and Navicula sp. were possible indicators of the upstream characteristics. Meanwhile, Cosmarium sp., Pinnularia sp., Surirella sp., Tabellaria sp., Synedra sp., Closterium sp. and Navicula sp. were possible indicators of the downstream characteristics. The PCA showed that the most important stream characteristics were DO, conductivity, Total Suspended Solids, water $\mathrm{pH}$, nitrate in water and water discharge, while conductivity, nitrate, phosphate, $\%$ organic matter, $\mathrm{pH}$, and $\%$ canopy cover were the types of substrate characteristics.
\end{abstract}

Keywords: Rainforest, stream characteristics, benthic algae, water quality, water discharge

\section{Introduction}

Streams in head waters are important to feed rivers due to its flow characteristics. Stream water flow depends on the incline and smoothness of the substrate, and cross sectional area of the stream. Streams are very sensitive ecosystems and the variation of stream characteristics and their impacts on biological composition is explained based on different ecological principles such as the river continuum concept (Vannote et al., 1980). The water flow is a major factor for determining the physical habitats such as cascades, riffles and pools in a

\footnotetext{
*Corresponding Author: asanthi@fish.ruh.ac.lk
}

stream. Also, the stability of the substrate of the stream and the interactions between the water flow and the local geology are important to explain how habitat influences on the distribution and abundance of algae (Bunn \& Arthingtom, 2002). The variations of streams morphology, biology and ecology from upper part of the stream to downstream also depend on the land use of streams catchment.

The benthic algae in streams occur as epiphytic or periphytic types and their diversity and distribution change with the nutrients, organic matter levels and the intensity of light. When the light intensity and nutrients are higher filamentous algae may grow enormously as periphyton communities. Some 
attached algae such as Pennate diatoms which are loosely retained with gelatinous bio films or are held within the tangled filamentous threads of such mature periphyton communities (Bellinger \& Sigee, 2010). When the temperature and light levels are higher, the blue green algae that grow attaching to the bottom sediment, rocks or submerged plants are become dominant in calm areas of the streams (Oram, 2014).

The distribution of benthic algae in streams can be influenced by the size, surface structure and chemistry of the substratum (Whitton, 1975). The alkalinity or acidity of water highly effects on the growth and reproduction of algae and therefore any deviation of water chemistry; water temperature and $\mathrm{pH}$ variations may cause problems in reproduction, ion exchange and viability of the aquatic organisms (Stoyan \& Hristov, 2011). Total Dissolved Solids (TDS) provide nutrients or contaminants such as organic pollutants and toxic metals for the algal growth (Weber-Scannell \& Duffy, 2007). However, the amount of Total Suspended Solids (TSS) attenuates light and reduces the transparency of water which is a negative factor for algal growth. According to Dodds \& Welch (2000), factors such as the geological variation, addition of toxic compounds, global changes, introduced species, watershed development and functions of other biotic and abiotic factors affect the variation of algal biomass.

In a stream, the abundance, biomass and the growth of particular benthic algae are considered as bioindicators (Dokulil, 2003). A good indicator species has a narrow ecological range, rapid response to environmental change, well defined taxonomy, reliable identification and a wide geographic distribution (Bellinger \& Sigee, 2010). The response to the natural or anthropogenic impacts can be early observed as specific stress symptoms in algae and therefore those are bio-sensors for environmental changes. Therefore, the land use of the catchment is predictable using benthic algal indicators of a stream which is important for the protection of sensitive ecosystems (Bellinger et al., 2010). Such types of studies are scanty in Sri Lanka and hence the knowledge is limited which would be important for the conservation and management aspects of stream ecosystems of Sri Lanka. The present study was focused to investigate the influence of variations of stream characteristics on the distribution of benthic algae at selected sites from upstream to downstream of the Gongawwa Ela in Kottawa Rainforest.

\section{Methodology}

\section{Site description}

Kottawa forest reserve $\left(6^{\circ} \quad 5^{\prime} 40.54 " \mathrm{~N}\right.$ and $\left.80^{\circ} 19^{\prime} 26.75^{\prime \prime} \mathrm{E}\right)$ is an isolated patch of low country rainforest located at Yakkalamulla divisional secretariat in Galle, Sri Lanka. Gongawwa Ela (tributary of Polathumodara River) which is located inside the Kottawa rainforest was selected for the current study (Figure 01). Two sites from the upper most part of the stream (site1, site 2) and two sites (site 3 , site 4 ) from the downstream were studied on monthly basis during the period of September to November 2016. Stream bank morphology and riparian vegetation were observed and were mapped using GPS (etrex 20X GARMIN) readings. The catchment of the selected part of the stream was delineated on the site and it was used to identify the major land use types in the area. 

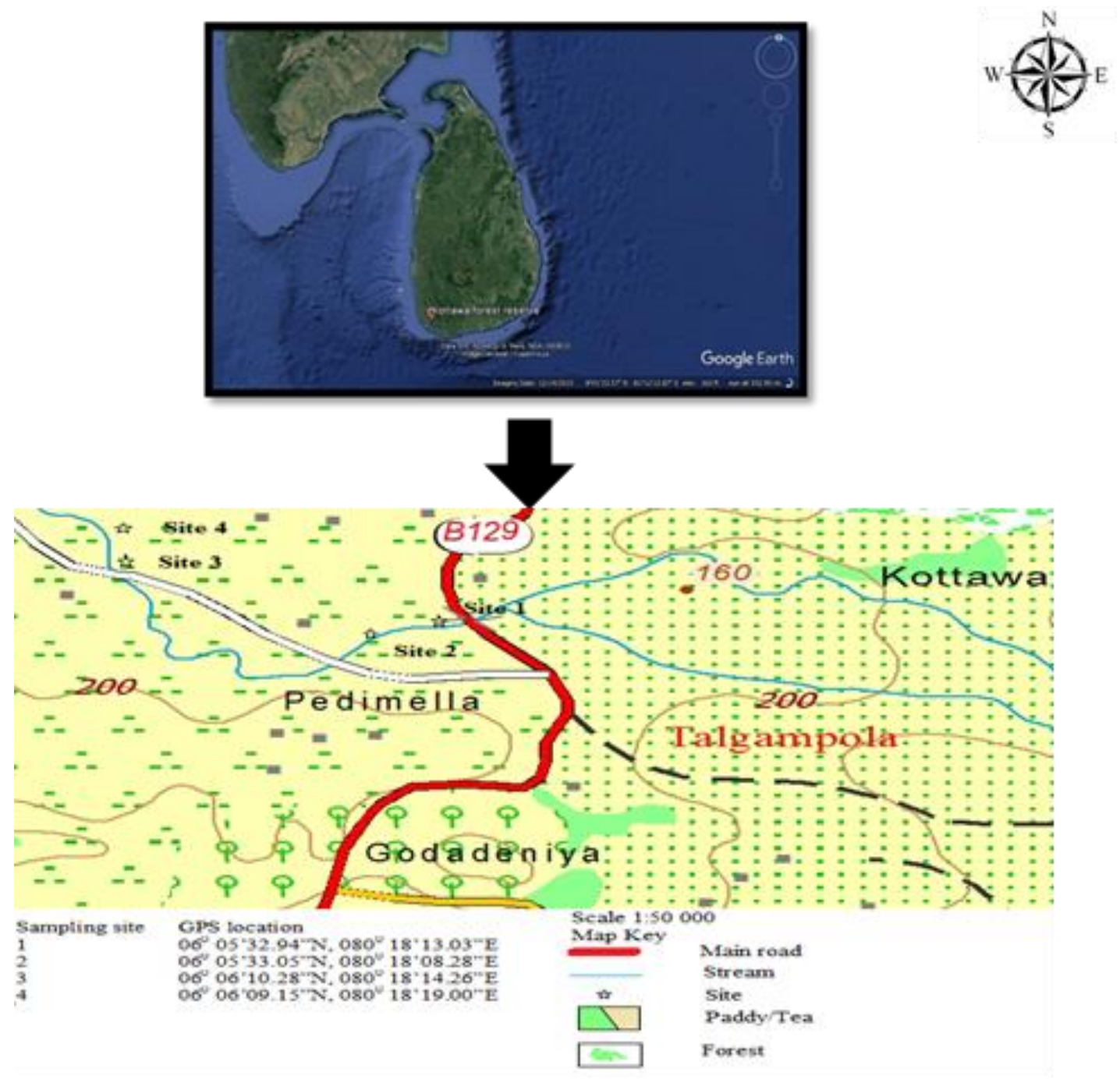

Figure 01: Locations of the four sampling sites

\section{Analysis of water quality}

Water quality parameters (water temperature, $\mathrm{pH}$, conductivity, surface light intensity, turbidity, nitrate and phosphate) were analyzed in three replicates of water samples at each site using standard instruments (Table 01) and following the standard methods (APHA, 1999). Sodium salicylate method was used to determine the nitrate levels both in water and the substrate as described by (Merck, 1974) and the absorbance was measured at $440 \mathrm{~nm}(\mathrm{HACH}$, DR3900). Ammonium molybdate method was used to determine the dissolved phosphorous levels both in water and the substrate (APHA, 1999).

Table 01: Instruments used for water quality analysis

\begin{tabular}{lll}
\hline Parameter & Units & Instrument \\
\hline Temperature & ${ }^{0} \mathrm{C}$ & Water Quality Meter(YSI Model 85) \\
\hline Conductivity & $\mu \mathrm{S} / \mathrm{cm}$ & Water Quality Meter(YSI Model 85) \\
\hline $\mathrm{pH}$ & & $\mathrm{pH}$ meter (EUTECH instrument) \\
\hline GPS Location & & GPS (etrex 20 X GARMIN) \\
\hline Light intensity & Lux & Lux meter (LX-101) \\
\hline Velocity & $\mathrm{m} / \mathrm{s}$ & Velocity meter (KENEK VP 1000) \\
\hline
\end{tabular}




\section{Determination of stream characteristics}

The following method was performed to determine the percentage of different grain sizes recorded in the substrate samples. Following the substrate classification method (ASTM D422- Standard Test Method for Particle-Size Analysis of Substrate) the mechanical sieve set with different pore sizes was used to determine the distribution of coarser, largersized particles and finer particles of the substrate samples. The \% value of a given particle type (Table 02 ) was calculated using the following equation.

$$
\% \text { value of a given particle type }=\frac{\text { weight of the given particle }}{\text { Total weight of the sample }} * 100 \%
$$

Table 02: Classification of the particle sizes of substrate

\begin{tabular}{lll}
\hline \multicolumn{1}{c}{ Particle size } & \multicolumn{1}{c}{ Class } & \multicolumn{1}{c}{ Texture } \\
\hline$<63 \mu \mathrm{m}$ & Mud & Smooth \& sticky \\
$63 \mu \mathrm{m}-0.25 \mathrm{~mm}$ & Fine sand & Smooth with some roughness \& not sticky \\
$0.25 \mathrm{~mm}-0.5 \mathrm{~mm}$ & Sand & Rough grainy texture \\
$0.5 \mathrm{~mm}-1 \mathrm{~mm}$ & Coarse sand & Coarse, particles loose \\
$1 \mathrm{~mm}<$ & Gravel & Very coarse, Small stones \\
\hline
\end{tabular}

The particle size distribution curves presented by semi-logarithmic graphs were plotted using the percentage of passing via each sieve of the mechanical sieve set. Three basic parameters of
Effective Size (D10), Uniformity Coefficient $(\mathrm{Cu})$, and Coefficient of Gradation $(\mathrm{Cc})$ were determined using the particle size distribution curves (Fig 02).

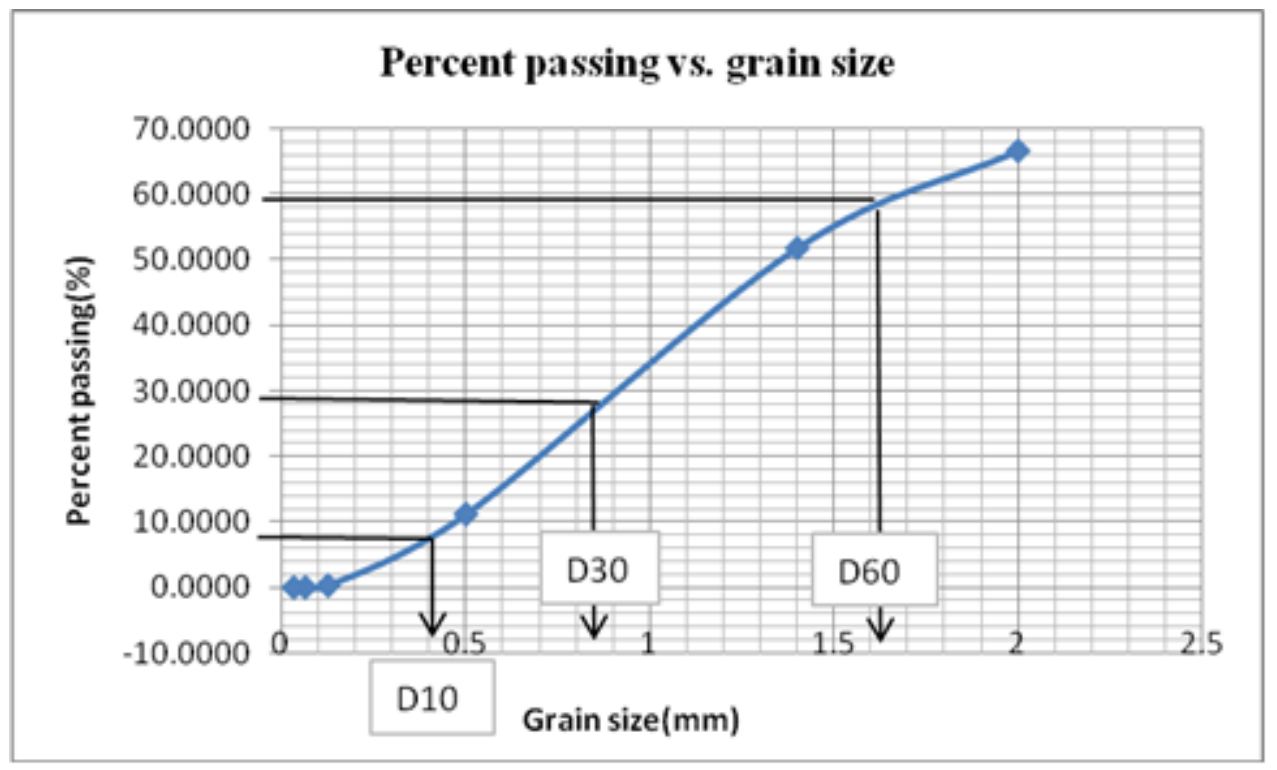

Figure02: Particle size distribution curve

$\mathrm{Cu}=\mathrm{D} 60 / \mathrm{D} 10$

$\mathrm{Cc}=\mathrm{D} 20 /(\mathrm{D} 60 \times \mathrm{D} 10)$

Criteria for grading substrate (Holtz \& Kovacs, 1981)

for gravel to be well graded as,

$$
\mathrm{Cu}>4 \& 1<\mathrm{Cc}<3
$$

For sand to be well graded,

$$
\mathrm{Cu}>=6 \& 1<\mathrm{Cc}<3
$$




\section{Water velocity and total water discharge}

In order to determine the stream discharge, the midsection method was used (Huber \& Bedient, 2002). Similar length portions were marked on a transect which was laid across the stream and the flow velocity was measured using velocity meter at half of

\section{Discharge per unit time $\left(\mathbf{m}^{3} / \mathbf{S}\right)=W 1 \times$ $D 1 \times \mathbf{V}$}

\section{Benthic algae sampling and analysis}

A transect was plotted across the two banks and the algae sampling was done by using a quadrate $(0.25$ $\mathrm{m}^{2}$ ) (TCEQ, 2014). Benthic algae were sampled carefully from hard substrates using a scraper and from soft substrates using a smooth brush and the samples were preserved in Lugol's iodine (1-2\%) (Hötzel \& Croome, 1999) and were transported to the

$$
N=\frac{n \times f}{A}
$$

Where,

$\mathrm{N}=$ Abundance of each species

The diversity of algae was calculated using different indices; Shannon-Weiner diversity, Pielou's evenness

$$
H^{\prime}=-\sum P i \ln P i
$$

H': Shannon index

Pi: Relative abundance of ith species

$$
J^{\prime}=\frac{H^{\prime}}{H^{\prime} \max }
$$

\section{Determination of canopy cover}

Light intensity of 25 points of each site was measured by Lux meter (LX-101). Then highest lux meter readings were removed and the mean value of light readings ( $\mathrm{I}$ mean $)$ was obtained. Then the values that are higher than $I$ mean $\times 3$ were excluded. This procedure was repeated until getting no more values for $I_{\text {mean }} \times 3$.

Canopy cover $(n)$

$=\frac{\text { Remaining number of readings } \times 100 \%}{\text { Total number of readings }}$

Forest canopy cover was estimated by, the total depth and total water discharge at each site was determined using a transect method at different depth of $1 \mathrm{~m}$ distance on the transect. Water discharge was calculated according to the following equation at each portions on the transect $(1 \mathrm{~m})$ and the total discharge was calculated using those values.

W1: length of the portion

D1: depth at the portion

$\mathrm{V}$ : water velocity at the portion

laboratory. The samples were identified using identification keys (Bellinger \& Sigee, 2010; Lund \& Lund, 1995; Presscott, 1954; Vuuren et al., 2005; Entwisle et al., 1997), enumerated using sedgewick rafter cell and the abundance was presented as number of cells or colonies per unit area. The abundance of each species was calculated using the equation given below.

$\mathrm{n}=$ Average number of algal cells counted in $1 \mathrm{~mL}$ of sample

$\mathrm{f}=$ Field conversion factor

$\mathrm{A}=$ Area of the quadrate $\left(\mathrm{m}^{2}\right)$

index and Menhinicks' species richness index (Shannon, 1948).

$J$ ': Pielou's evenness index

$H^{\prime}$ max: minimum value of $\mathrm{H}^{\prime}(\ln \mathrm{S})$

$$
D=S \sqrt{N}
$$

D: Menhnick's richness index

S: Number of species present in sample

$\mathrm{N}$ : Total number of individual organisms in the sample

\section{Statistical Analysis}

Spatial variation of different parameters were analyzed by using one way ANOVA tests and the correlations were analyzed between the biotic (species diversity, species richness) and the environmental factors. Principle Component Analysis was done to determine the most important factors which can be used for explaining the site specific characteristics of the stream. 


\section{Results and Discussion}

\section{Water and substrate quality}

Table 03 and 04 give the mean values of water quality parameters and substrate quality at each site respectively. The highest values of conductivity, phosphate concentration, and TSS were observed at the most downstream site. One way ANOVA showed that there was no significant spatial variation of the water quality parameters except for conductivity which also showed spatial variations in the substrate. However, there were significant temporal variations of water temperature, $\mathrm{pH}$, nitrate, $\mathrm{DO}$, TDS, substrate temperature, substrate $\mathrm{pH}$, phosphate, nitrate and organic matter in the substrate during the study period. The $\mathrm{pH}$ level of water was ranged from 6 to 7 which is favorable for algal growth. According to Alexander, (1997), green algae were dominated in acidic substrate while the diatoms and the blue green algae were less frequent in acidic substrate. The observed water $\mathrm{pH}$ range is suitable for the growth of oligotrophic algal species because the eutrophic species are growing at water $\mathrm{pH}$ above 9 (Moss, 1973). Lund \& Lund (1995) reported that nitrate and phosphate are the two most important elements which can effect on the growth of benthic algae. In the present study, highest abundance of algae ( $57330 \pm 11934$ individuals $/ \mathrm{m}^{2}$ ) was observed with the highest concentration of nitrate in the substrate $(2.60 \pm 0.7 \mathrm{mg} / \mathrm{L})$. Carrick \& Lowe, (1989) also reported that high biomass of green algae and diatoms at the water enriched with nitrate. However, the relationship between the algal species richness and phosphate levels in substrates was significantly negative $\left(\mathrm{R}^{2}=0.9592, \mathrm{P}<0.05\right)$ (Figure 03). After heavy rainfall in November, a comparative decline of substrate nitrate $(\mathrm{P}<0.05$ : One way ANOVA) and substrate phosphate were observed at each site except at the site 3 that located at downstream. Tea estates and home gardens were located at some places of the stream catchment and the agricultural runoff in the area may have enriched the phosphate and nitrate levels in the substrate. Oram, (2014) reported that phosphate in water can precipitate as iron phosphate or can be stored in partially decomposed organic matter in substrate and the latter process is more efficient at the neutral water $\mathrm{pH}$ (Busman et al., 2009). The phosphate and nitrate concentrations in substrate were statistically identified in PCA as important parameters for the changes of density and diversity of benthic algae in the stream.

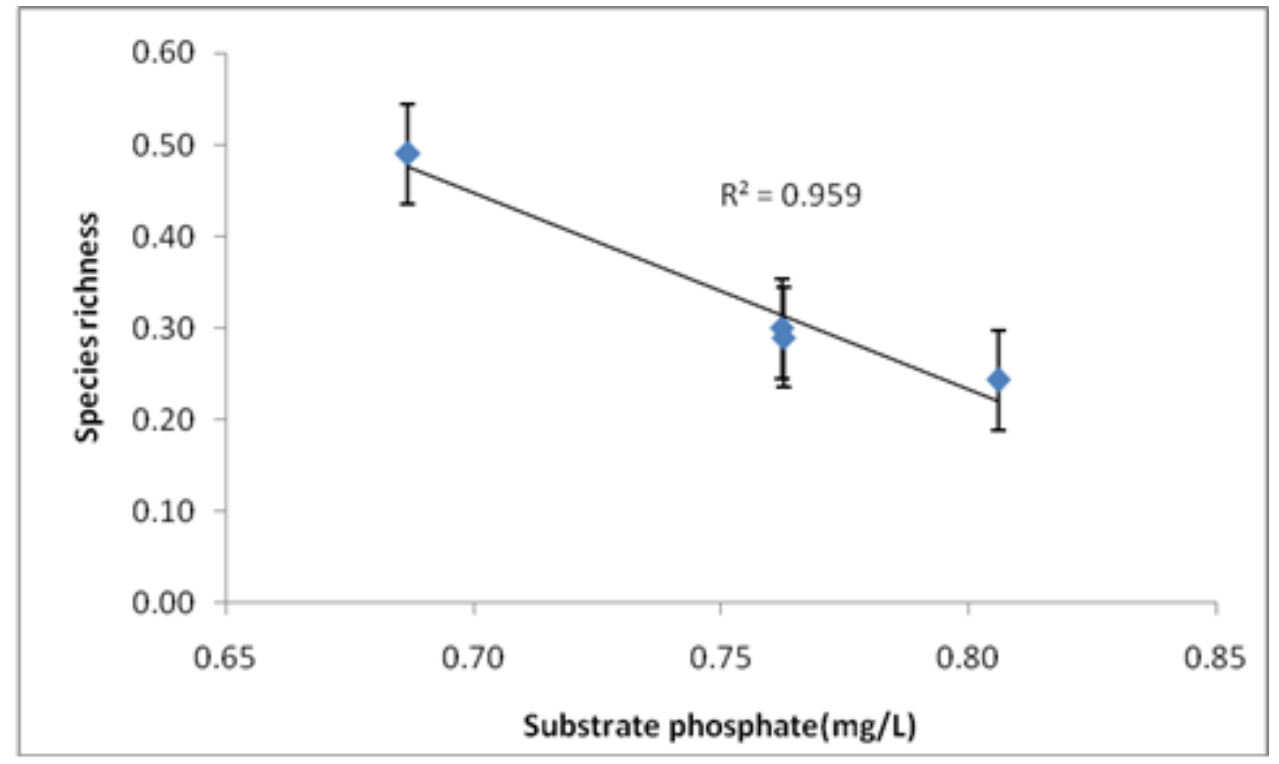

Figure 03: Correlation between substrate phosphate and species richness

\section{Stream characteristics}

Table 05 gives the percentage of retained on the mechanical sieve set at the four sites. The Figure 04 shows grain size distribution curves for the sites and the Table 06 gives the coefficient values at the sites.
The values for D60, D30 and D10 are shown in the Figure 04 for the sampling sites. The substrate consisted mostly with sand at all sites $(>98 \%)$ and well graded substrate was observed $(\mathrm{Cc}=1.2$, $\mathrm{Cu}=6.67)$ only at the site 3 which can be the reason for the highest species diversity and species richness 
observed especially at the rainy month. The organic matter content in the substrate did not vary significantly between the sampling sites $(\mathrm{P}>0.05$ : one way ANOVA) however; it was statistically identified as an important parameter in the stream characteristics (PCA). McIntire, (1968) explained a relationship between the algal communities and the organic matter content where the diatoms were dominated at low organic matter levels while blue green algae, chlorophyte and xanthophytes were abundant at high organic matter contents. The dominant algal group in the present study was diatoms while the chlorophytes were dominant with high organic matter content in the substrate. Moonsin et al. (2013) have observed high abundance of benthic algae in the period of late rainy season to early dry season in Mekong River passing through Ubon Ratchathani Province, Thailand. However, in the present study, benthic diatoms were abundant in early rainy season (October) and in the dry season (September) nevertheless the Shannon wiener index $(1.92 \pm 0.49)$ and species richness (25) were highest in the rainy period. Even though, the substrate conductivity varied significantly among the sites in the stream $(\mathrm{P}<0.05$, one way ANOVA) the substrate conductivity at the sites were relatively lower due to the high composition of sand in the substrate. Grisso et al. (2009) suggested that, conductivity correlates strongly with the particle size and the texture of substrate.

Table 03: Mean values of water quality parameters of the three months (Mean \pm SD).

\begin{tabular}{lcccc}
\hline \multicolumn{1}{c}{ Parameter } & Site 1 & Site 2 & Site 3 & Site 4 \\
\hline $\mathrm{pH}$ & $7.07 \pm 0.57$ & $7.2 \pm 0.35$ & $7.58 \pm 0.43$ & $7.29 \pm 0.29$ \\
Conductivity $(\mu \mathrm{S})$ & $247.76 \pm 78.7$ & $254.03 \pm 86.3$ & $213.66 \pm 46.0$ & $327.46 \pm 106.6$ \\
Temperature $\left({ }^{0} \mathrm{C}\right)$ & $28.6 \pm 0.85$ & $28.8 \pm 1.2$ & $28.2 \pm 1.1$ & $28.8 \pm 1.2$ \\
Nitrate $(\mathrm{mg} / \mathrm{L})$ & $0.687 \pm 0.37$ & $0.806 \pm 0.34$ & $0.882 \pm 0.42$ & $0.763 \pm 0.33$ \\
Phosphate $(\mathrm{mg} / \mathrm{L})$ & $0.036 \pm 0.667$ & $0.04 \pm 0.149$ & $0.029 \pm 0.112$ & $0.073 \pm 0.133$ \\
DO $(\mathrm{mg} / \mathrm{L})$ & $5.85 \pm 3.08$ & $6.05 \pm 2.56$ & $8.4 \pm 2.63$ & $7.66 \pm 2.12$ \\
$\mathrm{TSS}(\mathrm{mg} / \mathrm{L})$ & $0.014 \pm 0.003$ & $0.016 \pm 0.004$ & $0.015 \pm 0.004$ & $0.023 \pm 0.012$ \\
TDS $(\mathrm{mg} / \mathrm{L})$ & $1.007 \pm 0.97$ & $0.658 \pm 0.57$ & $1.029 \pm 0.93$ & $1.008 \pm 0.96$ \\
\hline
\end{tabular}

Table 04: Mean values of substrate quality parameters at the sites (Mean \pm SD).

\begin{tabular}{lcccc}
\hline Parameters & Site 1 & Site 2 & Site 3 & Site 4 \\
\hline $\mathrm{pH}$ & $6.82 \pm 0.42$ & $1.135 \pm 1.05$ & $1.107 \pm 1.11$ & $1.199 \pm 1.13$ \\
Conductivity $(\mu \mathrm{S})$ & $19.33 \pm 1.15$ & $18.00 \pm 2.00$ & $8.33 \pm 3.06$ & $15.67 \pm 5.86$ \\
Phosphate $(\mathrm{mg} / \mathrm{L})$ & $0.968 \pm 1.06$ & $1.135 \pm 1.05$ & $1.107 \pm 1.11$ & $1.199 \pm 1.13$ \\
Nitrate $(\mathrm{mg} / \mathrm{L})$ & $1.602 \pm 1.01$ & $1.681 \pm 1.33$ & $0.947 \pm 0.62$ & $1.63 \pm 1.53$ \\
Organic matter $(\%)$ & $1.88 \pm 0.266$ & $2.68 \pm 0.078$ & $2.97 \pm 0.355$ & $2.92 \pm 0.655$ \\
\hline
\end{tabular}

Table 05: The sieve size and percentage passing of the substrate

\begin{tabular}{ccccc}
\hline Sieve size $(\mathrm{mm})$ & Site $1(\%)$ & Site 2(\%) & Site 3(\%) & Site 4(\%) \\
\hline 2 & 77.52 & 68.05 & 59.33 & 61.85 \\
1.4 & 63.24 & 50.38 & 47.69 & 44.79 \\
0.5 & 17.45 & 12.65 & 17.65 & 9.46 \\
0.125 & 0.58 & 0.41 & 1.64 & 0.28 \\
0.063 & 0.09 & 0.05 & 1.12 & 0.09 \\
0.032 & 0.00 & 0.00 & 0.64 & 0.00 \\
\hline
\end{tabular}

Table 06: Coefficient values and the classification of the substrate

\begin{tabular}{llll}
\hline Site & $\mathrm{C}_{\mathrm{U}}$ & $\mathrm{C}_{\mathrm{C}}$ & Grading of sand \\
\hline 1 & 3.71 & 1.24 & Poorly graded \\
2 & 3.4 & 0.95 & Poorly graded \\
3 & 6.67 & 1.20 & Well graded \\
4 & 3.9 & 1.03 & Poorly graded \\
\hline
\end{tabular}




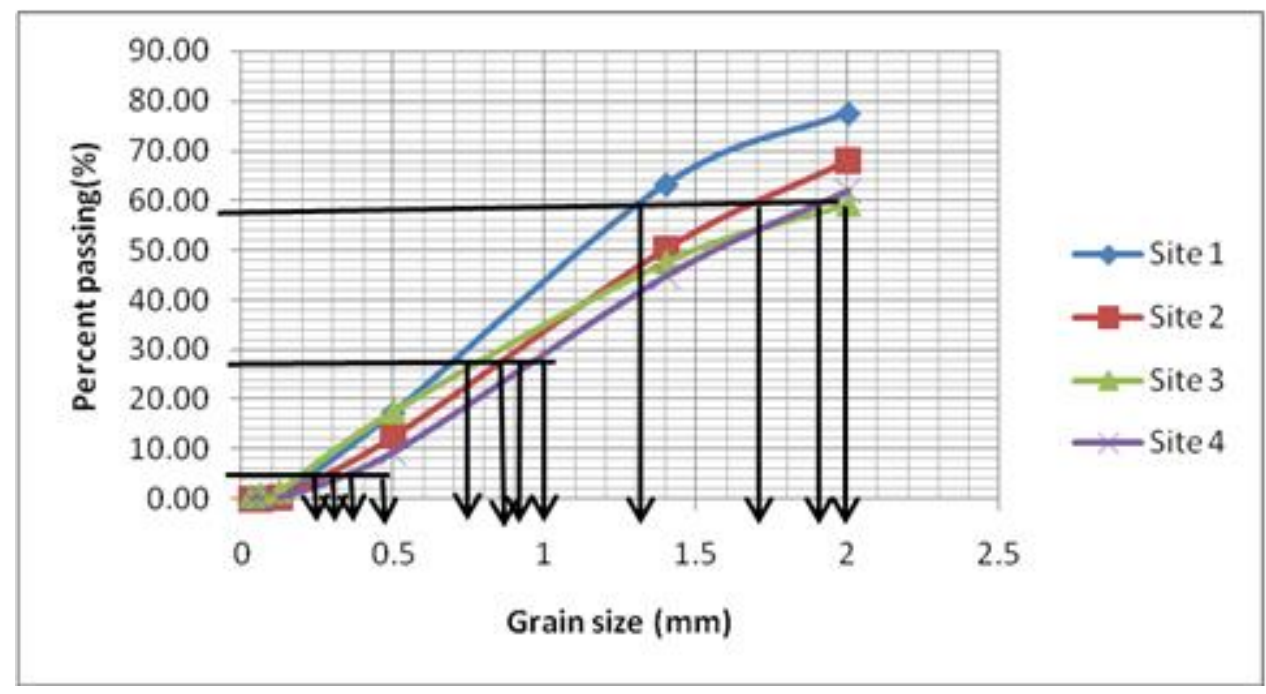

Figure 04: The semi logarithmic graph for percentage of passing vs. grain size at the sites

\section{Water velocity and discharge}

The monthly data for water velocity and discharge at the sites are given in the Table 07. The highest stream velocity and water discharge were observed at the site 3 (downstream). The oneway ANOVA explained significant difference $(\mathrm{P}<0.05)$ of water velocity among sites. The water velocity was high at the most down part of the stream due to the elevation difference of the area and it was one of the statistically important parameters in the stream. Therefore, relatively low abundance and high species diversity of benthic algae was observed at the downstream sites 3 and 4 . The lowest velocity of the stream was recorded in October which caused low removal of attached diatoms. Allan \& Castill, (1999) suggested that the flood condition is creating unstable nutrient supply resulting favorable conditions for the diatoms.

Table 07: Mean velocity and discharge at the sites

\begin{tabular}{lllllll}
\hline Site & September & & October & & November \\
\hline & $\begin{array}{l}\text { Velocity } \\
(\mathrm{m} / \mathrm{s})\end{array}$ & $\begin{array}{l}\text { Discharge } \\
\left(\mathrm{m}^{3} / \mathrm{s}\right)\end{array}$ & $\begin{array}{l}\text { Velocity } \\
(\mathrm{m} / \mathrm{s})\end{array}$ & $\begin{array}{l}\text { Discharge } \\
\left(\mathrm{m}^{3} / \mathrm{s}\right)\end{array}$ & $\begin{array}{l}\text { Velocity } \\
(\mathrm{m} / \mathrm{s})\end{array}$ & $\begin{array}{l}\text { Discharge } \\
\left(\mathrm{m}^{3} / \mathrm{s}\right)\end{array}$ \\
1 & $0.068 \pm 0.06$ & 0.0984 & $0.0295 \pm 0.04$ & 0.0133 & $0.078 \pm 0.02$ & 0.1654 \\
2 & $0.055 \pm 0.01$ & 0.0867 & $0.004 \pm 0.01$ & 0.0022 & $0.2517 \pm 0.10$ & 0.3995 \\
3 & $0.3275 \pm 0.37$ & 0.4975 & $0.294 \pm 0.04$ & 0.0529 & $0.611 \pm 0.20$ & 0.2475 \\
4 & $0.1112 \pm 0.07$ & 0.2829 & $0.0255 \pm 0.01$ & 0.1031 & $0.3253 \pm 0.19$ & 1.0801 \\
\hline
\end{tabular}

\section{Benthic algae diversity and distribution}

Twenty nine algal genera belonging to Divisions Bacillariophyta, Chlorophyta, Cyanophyta, Xanthophyta and Rhodophyta (Table 08) were identified. The most abundant benthic algal division was Bacillariophyta (18 diatom genera/species). Among those genera the common diatoms were Flagilaria sp., Synedra sp., Aulacoseira sp., Gomphonema sp., Navicula sp. and Nitzchia sp. Three blue green algae were recorded as Anabaena sp.,

Oscillatoria

sp. and Lyngbia sp. Among them, Anabaena sp. and Oscillatoria sp. were highly abundant. Seven genera of green algae were recorded as Spyrogyra sp., Stigeoclonium sp., Chaetophora sp., Closterim sp. Cylindrocystis sp., Cosmarium sp. and Pediastrum sp. where Stigeoclonium sp. and Chaetophora sp. were common. One genus from Rhodophyta as Chroodactylon sp. and one genus from Xanthophyta as Vaucheria sp. were recorded in the stream. Flagilaria sp., Synedra sp., Aulacoseira sp., Gomphonema sp., Navicula sp. and Nitzchia sp. were the most abundant diatoms at all the four sites in the stream which could be considered as possible bioindicators in the Gongawwa Ela. The most upstream sites represented by Pinnularia sp., Synedra sp., Anabaena sp. and Navicula sp.. The species recorded 
from the most downstream sites were Cosmarium sp., Pinnularia sp., Surirella sp., Navicula sp., Tabellaria sp., Syendra sp., Closterium sp., Flagilaria sp., Nitzchia sp., Gomphonema sp. and Aulacoseira sp.. Akinyemi et al. (2007) have recorded Pinnularia sp. as a good bio-indicator for water pollution and this alga was observed at site 1, 3 and 4 in the present study. Cosmarium sp. which was recorded from most downstream (site 3 and site 4 ) is resistant to the increasing of stream velocity and nutrient depletion. The highest diversity of desmids has been observed in summer months when $\mathrm{pH}$, conductivity and total hardness were low (Stamenković \& Cvijan, 2009). Also, desmids have been used for assessing the water quality of freshwater resources (Ngearnpat \& Peerapornpisal, 2007). Anabaena sp. was recorded only from site 2 located in the upstream. According to Douterelo et al. (2004), the community composition of cyanobacteria changes with water quality and therefore they can be used for environmental studies in riverine ecosystems. Surirella sp. which is resistant to water flow and water pollution (Hill et al., 2001) was found only from the site 3 (downstream) in which the substratum was well graded. Tabellaria sp. and Gomphonema sp. have been assigned as indicators for moderate health in the Coopers Creek catchment of Australia and those algae were recorded during the current study only at the most downstream site.

Some genera of benthic algae were found only in one sampling site and those could be considered as possible bio-indicators of the stream; Vaucheria sp. and Chroodactylon sp. were recorded only in dry period from the upstream site, Cylindrocystis sp. was recorded only in September from the upstream site. The highest relative abundance of Flagilaria sp. was found from the sites 2,3 and $4(\mathrm{P}<0.05$ : One way ANOVA) at dry the month where the nutrient concentrations were increased. Spirogyra sp. was observed both in wet (September) and dry (November) months. According to Allan \& Castill, (1999), the dry season with low velocities is more favorable for the colonization and growth of Spirogyra sp.. The maximum abundance of filamentous algae was recorded in November just after heavy rainfall and high discharge at the downstream (site 4).

Benthic algae abundance was not varied significantly among the four sampling sites $(\mathrm{P}>0.05$ : one way ANOVA). However, the abundances of Flagilaria sp., Pinnularia sp., Stigeoclonium sp. and Pediastrum sp. showed significant monthly variations. Mean abundance (individuals $/ \mathrm{m}^{2}$ ) of Flagilaria sp., Pinnularia sp. and Pediastrum sp. showed their highest values $(5548 \pm 3487,971 \pm 770$ and $13 \pm 10$ respectively) in October. The mean abundance of Stigeoclonium sp. was highest in November $\left(43 \pm 22\right.$ individuals $\left./ \mathrm{m}^{2}\right)$. Shannon Weiner Diversity index value, evenness and dominance for each month at each site are given in the Table 09. The highest diversity index value of 2.45 was observed at a downstream site (site 03) with the most alkaline water $\mathrm{pH}(\geq 8.00)$ and on the well graded substrate during the rainy period in November and the lowest index value 1.23 was recorded at the upstream site (site 2) during the dry period in October.

Table 08: The mean abundance (number of individuals $/ \mathrm{m}^{-2}$ ) of algal groups at the sampling sites during the study period.

\begin{tabular}{|c|c|c|c|c|c|}
\hline Month & Site & & & & \\
\hline \multirow{3}{*}{ September } & Division & 1 & 2 & 3 & 4 \\
\hline & Bacillariophyta & $7536 \pm 1042$ & $1648 \pm 157$ & $1240 \pm 149$ & $1504 \pm 241$ \\
\hline & Chlorophyta & $108 \pm 23$ & $132 \pm 40$ & $1676 \pm 625$ & $8 \pm 2$ \\
\hline \multirow{6}{*}{ October } & Cyanophyta & $8 \pm 0$ & $56 \pm 18$ & $86 \pm 0$ & $172 \pm 0$ \\
\hline & Xanthophyta & $28 \pm 0$ & $0 \pm 0$ & $0 \pm 0$ & $0 \pm 0$ \\
\hline & Rhodophyta & $4 \pm 0$ & $0 \pm 0$ & $0 \pm 0$ & $0 \pm 0$ \\
\hline & Bacillariophyta & $680 \pm 45$ & $7872 \pm 1232$ & $25336 \pm 2634$ & $22768 \pm 2305$ \\
\hline & Chlorophyta & $4 \pm 2$ & $24 \pm 9$ & $24 \pm 6$ & $184 \pm 25$ \\
\hline & Cyanophyta & $38 \pm 18$ & $76 \pm 26$ & $88 \pm 30$ & $236 \pm 98$ \\
\hline \multirow{5}{*}{ November } & Xanthophyta & $0 \pm 0$ & $0 \pm 0$ & $0 \pm 0$ & $0 \pm 0$ \\
\hline & Bacillariophyta & $300 \pm 21$ & $1612 \pm 251$ & $804 \pm 54$ & $400 \pm 32$ \\
\hline & Chlorophyta & $64 \pm 18$ & $328 \pm 97$ & $72 \pm 25$ & $1708 \pm 618$ \\
\hline & Cyanophyta & $4 \pm 2$ & $56 \pm 32$ & $780 \pm 350$ & $80 \pm 46$ \\
\hline & Xanthophyta & $0 \pm 0$ & $0 \pm 0$ & $0 \pm 0$ & $0 \pm 0$ \\
\hline
\end{tabular}


Table 9: Diversity index values at each site

\begin{tabular}{llllll}
\hline Period & Site & Shannon diversity & Evenness & Dominance & Species richness \\
\hline September & 1 & 1.31 & 0.45 & 0.55 & 0.18 \\
& 2 & 2.04 & 0.69 & 0.31 & 0.35 \\
& 3 & 1.39 & 0.47 & 0.53 & 0.24 \\
October & 4 & 1.41 & 0.48 & 0.52 & 0.41 \\
& 1 & 2.21 & 0.7 & 0.3 & 0.51 \\
& 2 & 1.23 & 0.39 & 0.61 & 0.13 \\
November & 3 & 1.79 & 0.57 & 0.43 & 0.11 \\
& 4 & 1.96 & 0.62 & 0.38 & 0.13 \\
& 1 & 2.36 & 0.73 & 0.27 & 0.78 \\
& 2 & 1.55 & 0.48 & 0.52 & 0.25 \\
& 3 & 2.45 & 0.76 & 0.24 & 0.55 \\
\hline
\end{tabular}

\section{Canopy cover}

The canopy covers from upstream to downstream of the site $1,2,3$, and 4 were $96 \pm 0.0 \%, 94 \pm 2.83 \%$, $92 \pm 5.66 \%$ and $86 \pm 8.49 \%$ respectively. Canopy cover was relatively higher at the upstream sites and lowest at downstream sites.

\section{Principle Component Analysis}

The percentage variances represented by the component 1,2 and 3 were $47 \%$ and $34 \%$ and $19 \%$ respectively. The factor values for different parameters in the two components are tabulated (Table 10). Substrate conductivity, water $\mathrm{pH}$, substrate nitrate, organic matter, nitrate in water and substrate $\mathrm{pH}$ highly contributed to the component 1 and those can be used to explain the stream characteristics on algae distribution. Similarly, the water discharge, water conductivity, substrate phosphate, TSS and canopy cover (\%) highly contributed to the component 2 and those also can be used to explain the stream characteristics on algal growth.

Table 10: Factor values for different parameters at the two components

\begin{tabular}{lcc}
\hline Parameter & Component 1 & Component 2 \\
\hline Discharge & 0.148 & $\mathbf{0 . 9 7 5}$ \\
Water conductivity & -0.366 & $\mathbf{0 . 8 9 2}$ \\
Substrate conductivity & $\mathbf{- 0 . 9 7 9}$ & -0.240 \\
DO & $\mathbf{0 . 8 9 1}$ & 0.398 \\
Water pH & $\mathbf{0 . 9 9 6}$ & $\mathbf{0 . 8 2 0}$ \\
Substrate phosphate & 0.449 & $\mathbf{0 . 8 4 3}$ \\
Nitrate in water & $\mathbf{0 . 9 3 6}$ & 0.029 \\
TDS & 0.232 & 0.088 \\
Temperature & -0.522 & -0.688 \\
TSS & -0.026 & $\mathbf{0 . 9 9 6}$ \\
Substrate pH & -0.328 & 0.652 \\
Velocity & $\mathbf{0 . 9 7 0}$ & -0.56 \\
Substrate nitrate & $\mathbf{- 0 . 8 7 9}$ & 0.295 \\
Phosphate in water & -0.728 & -0.558 \\
BOD & 0.310 & -0.497 \\
Organic matter & $\mathbf{0 . 8 0 0}$ & 0.597 \\
Canopy cover & -0.335 & $\mathbf{- 0 . 9 5 3}$ \\
\hline
\end{tabular}




\section{Conclusions}

Water $\mathrm{pH}$, conductivity, concentrations of nitrate and phosphate were the parameters that mostly influenced on the stream characteristics of Gongawwa Ela. Discharge and the velocity of water and some of the substrate characteristics such as nitrate, phosphate and organic matter content were identified as important factors for the variation of diversity and distribution of benthic algae. Also, high diversity and species richness of algae was observed at the downstream sites having an alkaline water $\mathrm{pH}$ and well graded substrate. Diatoms (Bacillariophyta) were the most dominant benthic algae in the stream

\section{References}

Akinyemi, S.A., Nwankwo, S.A. \& O, F.A., (2007), Diatoms as Indicator of Pollution in Awon Reservior. Research Journal of Microbiology, 2, pp.228-38.

Alexander, M., (1977), Introduction to substrate microbiology. 2nd ed. New York: JohWiley \& sons, Inc.

Allan, J.D. \& Castill, M.M., (1999), Primary producers. In Stream ecology: Structure and function of running water. 2nd ed. Springer. pp.105-134.

APHA, (1999), Standard Methods for the Examination of Water and Wastewater. 19th ed. American Public Health Association, American Water Works Association, Water Environment Federation.

ASTM, (1998), Standard test method for particle-size analysis of substrates. [Online] ASTM Available at: HYPERLINK "https://fenix.tecnico.ulisboa.pt/downloadFile/.../ D422-particle\%20size.pdf"

https://fenix.tecnico.ulisboa.pt/downloadFile/./D 422-particle\%20size.pdf [Accessed 13 December 2016].

Bellinger, E.G. \& Sigee, D.C., (2010), Freshwater Algae: Identification and Use as Bioindicators. John Wiley \& Sons Ltd.

Bunn, S.E. \& Arthingtom, A.H., (2002), Basic principles and ecological consequences of altered flow regimes for aquatic biodiversity. Environmental management, 30(4), pp.492-507. and they were mostly present at low organic matter content whilst Chlorophytes were dominant at high organic matter contents. High abundance of benthic algae was observed at high nitrate and phosphate in the substrate. Aulacoseira sp., Flagilaria sp, Tabellaria sp. and Nitzchia sp. were the most abundant algae in the stream and can be considered as possible bio-indicators when observed stream characteristics. However, identification of indicator benthic algae for different land use patterns in stream catchments is recommended to study lengthier as an important assessment tool of river systems in Sri Lanka.

Busman, L., Lamb, J., Randall, G., Rehm, G. \& Schmitt, M., (2009), University of Minnesta. [Online] University of Minnesta Available at: HYPERLINK

"http://www.extension.umn.edu/agriculture/nutri ent-management/phosphorus/the-nature-ofphosphorus/"

http://www.extension.umn.edu/agriculture/nutrie nt-management/Phosphorus/the-nature-ofPhosphorus/ [Accessed 28 December 2016].

Carrick, H.J. \& Lowe, R.L., (1989), Benthic algal response to $\mathrm{N}$ and $\mathrm{P}$ enrichment along a $\mathrm{pH}$ gradient. Hydrobiologia, pp.119-27.

Dodds, W.K. \& Welch, E.B., (2000), Establishing nutrient criteria in streams. Jornal of North American benthological society, 19, pp.186-196.

Dokulil, M.T., (2003), Bioindicators and biomonitors. Elsvier science Ltd.

Entwisle, T.J., Soneman, J.A. \& Lewis, S.H., (1997), Freshwater algae in Australia: a guide to conspicous genera. Sainty \& Associates pvt Ltd.

Grisso, R., Alley, M., Holshouser, D. \& Thomason, W., (2009), Precision Farming Tools: Substrate Electrical Conductivity. Petersberg: Verginia tech Virginia polytechnic insitute and state university.

Hill, B.H., Stevenson, R.J., Pan, Y., Herlihy, A.T., Kaufmann, P.R. \& Johnson, C.B., (2001), Comparison of correlations between environmental characteristics and stream diatom assemblages characterized at genus and species levels. J. N. Am. Benthol. Soc, 20++(2), pp.299310 . 
Holtz, R. \& Kovacs, W., (1981), An introduction to Geotechnical Engineering. Prentice-Hall.

Hötzel, G. \& Croome, R., (1999), A phytoplankton methods manual for Australian freshwaters. Canberra: Land and Water Resources ReseArch and Development Cooperation.

Huber, W.C. \& Bedient, P.B., (2002), Hydrology and flood plain analysis. 3rd ed. Prentice halle.

Lund, H.C. \& Lund, J.W.G., (1995), Freshwater algae: Their microscopic world explored. Bristol, England: Biopress limited.

Merck, E., (1974), The testing of water. 10th ed. Darmstadt: Merck publications.

Moonsin, P., Peerapornpisal, Y., Rott, E., Pipp, E. \& Pimmongkol, A., (2013), Diversity of Benthic Diatoms and Water Quality of the Mekong River Passing Through Ubon Ratchathani Province, Thailand. Research Journal of Environmental and Earth Sciences, 5(2), pp.58-66.

Moss, B., (1973), The Influence of Environmental Factors on the Distribution of Freshwater Algae: An Experimental Study: II. The Role of $\mathrm{pH}$ and the Carbon DioxideBicarbonate System. Journal of Ecology, 61(1), pp.157-77.

McIntire, C.D., (1968), Structural characteristics of benthic algal communities in laboratory streams. Ecological society of America, 49 (3), pp. 520-537.

Ngearnpat, N. \& Peerapornpisal, Y., (2007), Application of desmid diversity in assessing the water quality of 12 freshwater resources in Thailand. J Appl Phycol, 19, pp.667-74.

Oram, B., (2014), Phosphate in water. [Online] Water Research Watershed Center Available at: HYPERLINK "http://www.waterresearch.net/index.php/phosphate-in-water" http://www.waterresearch.net/index.php/phosphate-in-water [Accessed 1 January 2017].

Oram, B., (2014), Water research center. [Online] Available at: HYPERLINK "http://www.water-

research.net/index.php/phosphate-in-water" http://www.water- research.net/index.php/phosphate-in-water [Accessed 28 December 2016].

Presscott, G.W., (1954), How to know the fresh water algae. USA: WM.C Brown company.

Shannon, C.E., (1948), A Mathematical Theory of Communication. The Bell System Technical Journal, 27, pp.PP-379-423.

Stamenković, M. \& Cvijan, M., (2009), Desmid flora (Chlorophyta, Zygnematophyceae) of the river Tisa in the Province of Vojvodina (Northern Serbia). Botanica serbica, 33(1), pp.89-99.

Stoyan, M. \& Hristov, I., (2011), River Ecology. Translated by K. Ancheva. Vienna: WWF Danube Carpathian Programme.

TCEQ, (2014), Benthic algae and aquatic macrophytes. Manual script. Texas: Texas Commission on Environmental Quality Texas Commision on environmental quality.

Vannote, R.L., Minshall, G.W., Cummins, KW., Sidell, J R. \& Cushing, C.E., (1980), River continuum concept. Canada journal of fish aquatic science, 37, pp.p130-137.

Vuuren, S.J.V., Taylor, j., Ginkel, C.V. \& Gerber, A., (2005), Easy identification of the most common freshwater algae. Northwest university and department of water affairs and forestry.

Weber-Scannell, P.K.W. \& Duffy, L.K., (2007), Effects of Total Dissolved Solids on Aquatic Organisms: A Review of Literature and Recommendation for Salmonid Species. American Journal of Environmental Sciences , 3(1), pp.1-6.

Whitton, B.A., (1975), River ecology. London: Blackwell scientific publications. 